\title{
TANTANGAN MEMBACA SURABAYA 2015: \\ MERETAS JALAN MEMBANGUN LABORATORIUM KOLABORATIF PEMBUDAYAAN LITERASI YANG EFEKTIF BAGI MASA ADOLESEN
}

\author{
Chamim Rosyidi Irsyad**) \\ SMP Negeri 21 Surabaya \\ (chrirs_admojo@yahoo.com / chrirs.admojo@gmail.com)
}

\begin{abstract}
ABSTRAK
Data mutakhir TIMSS dan PIRLS 2011 serta PISA 2012 menginformasikan bahwa tingkat literasi bangsa Indonesia pada urutan bawah di percaturan global. Riset Taufiq Ismail tahun 1996 menyatirekan bahwa siswa SMA di Indonesia "rabun membaca dan pincang menulis". Ikhtiar-ikhtiar yang dilakukan kelompokkelompok pegiat literasi di Indonesia telah membuktikan hasilnya yang beraneka. Namun, jika jejak langkah ini tidak ditantang oleh sistem pembudayaan literasi yang pasti dan visioner, teresekusi di jalur-jalur pendidikan -informal, formal, dan nonformal-, terukur, termonitor dan terevaluasi, serta terkesinambungan, kapankah peluang akselerasi gerakan literasi membuahkan generasi emas yang diidamkan? Pencanangan Surabaya Kota Literasi telah dilakukan Walikota Surabaya pada 2 Mei 2014. Pada 2 s.d. 5 Maret 2015 program Tantangan Membaca Surabaya 2015 telah dilaunching oleh Kepala Dinas Pendidikan Kota Surabaya. Dua kebijakan ini meski belum menjadi sistem yang menjamin kepastian keberlangsungan gerakan, sebagai embrio lahirnya Perda dan Perwali tentang gerakan literasi, ia telah melempangkan teretasnya jalan membangun laboratorium kolaboratif guna pembudayaan literasi (LabKobuLi) yang efektif bagi para generasi bangsa usia adolesen. Dengan LabKobuLi inilah gerakan pengeberaksaraan diberlangsungkan dengan semangat hari ini lebih baik daripada kemarin dan esok lebih baik daripada hari ini. Untuk menyukseskan gerakan pioner ini, pemeranan dan pemungsian kepemimpinan pembelajaran sangat diperlukan.
\end{abstract}

Kata kunci: budaya literasi, gerakan literasi, pembiasaan literasi, laboratorium kolaboratif pembudayaan literasi

"Kita tidak berpesta panen padi di sawah, melainkan kita berpesta panen padi yang kita tanam di sawah."

(Multatuli)

\section{PENDAHULUAN}

Hasil survei internasional TIMSS dan PIRLS 2011 serta PISA 2012 menginformasikan bahwa tingkat literasi anak-anak Indonesia usia 15-16 tahun

${ }^{* *}$ Guru Bahasa Indonesia dengan tugas tambahan sebagai Kepala SMP Negeri 21 Surabaya 
menorehkan prestasi literasi pada urutan bawah di percaturan global ${ }^{1}$. Satire Taufiq Ismail bahwa bangsa Indonesia "rabun membaca dan pincang menulis" pun telah diproklamasikan sejak purna meriset sejumlah SMA di 13 negara amanat UNESCO pada 1996an. Di Pekanbaru tepat sepuluh tahun yang lalu pun (31 Mei 2005) Taufiq Ismail menyatakan bahwa "Tragedi Nol Buku, Tragedi Kita Bersama”. Ia sampai pada kegeramannya menyampaikan simpulan bahwa rezim Linguistik menguasai pelajaran Bahasa dan Sastra lebih dari setengah abad lamanya, di Indonesia. Para siswa tidak diberi kesempatan berenang di danau kesusastraan dengan nikmatnya (Ismail, 2005). Ikhtiar-ikhtiar yang dilakukan kelompok-kelompok pegiat literasi di seantero Nusantara telah berjumlah pula dan kini membuktikan hasilnya yang beraneka². Namun, jika jejak langkah ini tidak ditantang oleh kepastian sistem pembudayaan literasi yang dinamis dan visioner, teresekusi di jalur-jalur pendidikan -informal, formal, dan nonformal-, terukur, termonitor dan terevaluasi, serta terkesinambungan, kapankah peluang akselerasi gerakan literasi membuahkan generasi emas yang diidamkan?

Pencanangan Surabaya Kota Literasi telah dilakukan Walikota Surabaya pada 2 Mei 2014. Pada 2 s.d. 5 Maret 2015 program Tantangan Membaca Surabaya 2015 (TMS 2015) telah dilaunching oleh Kepala Dinas Pendidikan Kota Surabaya. Dua kebijakan ini meski belum menjadi sistem yang menjamin kepastian keberlangsungan gerakan, sebagai embrio lahirnya Perda dan Perwali tentang budaya literasi, ia telah melempangkan teretasnya jalan membangun laboratorium kolaboratif guna pembudayaan literasi.

Sasaran program TMS 2015 ini adalah siswa usia sekolah, termasuk di dalamnya usia masa remaja, adolesen. Merujuk pada pandangan Erikson (2010: 309-312; Santrock, 2007: 191-192) dalam teori psikososialnya, mengenai identitas yang terjadi pada perkembangan selama masa adolesen, diungkapkan bahwa tahap kelima, dari delapan tahap usia manusia ${ }^{3}$, berupa tahap identitas versus kebingungan identitas (identity versus identity confusion). Di masa ini, remaja galau untuk menentukan siapakah diri mereka itu, apakah keunikan dirinya, dan apa yang menjadi tujuan hidupnya. Mereka berada pada masa antara "rasa aman masa kanak-kanak" dan "otonomi di masa dewasa". Remaja 
mengalami masa ini sebagai bagian dari eksplorasi identitasnya. Pikiran remaja, menurut Erikson, pada dasarnya adalah pikiran moratorium, tahap psikososial di antara masa kanak-kanak dan masa dewasa, dan antara moralitas yang dipelajari oleh anak dan etika yang akan dikembangkan oleh orang dewasa (Erikson, 2010: 312; Santrock, 2007: 191).

Dengan mempertimbangkan kondisi seperti sekilas gambaran ini, pada masa adolesen inilah potensial dikembangkan keterampilan berpikir kritis dan berpikir tingkat tinggi. Hakikinya, keterampilan berpikir kritis dan berpikir tingkat tinggi tidak hanya berpeluang dikembangkan secara masif pada masa adolesen ini, tetapi sesungguhnya keterampilan berpikir kritis dan berpikir tingkat tinggi merupakan keperluan bagi para remaja.

Dalam kaitannya dengan berpikir tingkat tinggi, Anderson, dkk. (2001), murid-murid dan sahabat-sahabat Benyamin S. Bloom yang telah merivisi dan menyempurnakan Taksonomi Bloom, memiramidkan domain kognisi menjadi dua tingkatan. Lower Order Thinking Skills dan Higher Order Thinking Skills. Pada piramida bagian bawah sampai tengah ada kelompok Lower Order Thinking Skills (LOTS), sedangkan pada bagian tengah sampai bagian atas piramida disebut kelompok Higher Order Thinking Skills (HOTS). LOTS meliputi Remembering, Understanding, dan Applying. HOTS meliputi Analyzing, Evaluating, dan Creating. (Anderson, 2001: 231-232).

Berkaitan dengan tingkatan dan kemampuan berpikir, LOTS dan HOTS sangat erat dengan kecerdasan seseorang. Howard Gardner menyatakan bahwa kecerdasan lebih berkaitan dengan kapasitas (1) memecahkan masalah dan (2) menciptakan produk baru di lingkungan yang kondusif dan alamiah (Garner, 1983). Apabila perspektif yang lebih luas dan lebih pragmatis diterima, konsep kecerdasan tidak lagi menjadi sekedar mitos, tetapi menjadi konsep fungsional yang dapat ditemui dalam kehidupan sehari-hari dengan beragam cara (Arsmtrong, 2004: 2). Gardner memetakan lingkup kemampuan manusia yang luas menjadi delapan kategori yang komprehensip atau disebut dengan delapan kecerdasan dasar ${ }^{4}$. 
Beberapa penelitian mutakhir menyimpulkan bahwa pembelajaran dengan cara-cara berbasis KM sangat efektif dan menyenangkan, tetapi bagaimana cara merekam kemampuan siswa selama proses dan pada akhir proses sebagai evaluasi kemajuan proses pembelajaran siswa. Sesungguhnya, teori KM Gardner menawarkan perombakan yang fundamental dalam menilai kemajuan pembelajaran siswa. Teori ini menganjurkan sistem yang tidak bergantung pada tes standar atau tes yang didasarkan pada norma formal, tetapi didasarkan pada penilaian autentik.

Selanjutnya, dengan TMS 2015 dan untuk menyukseskan gerakan pioner ini, sistem penghargaan dan motivasi, serta pemeranan dan pemungsian kepemimpinan pembelajaran sangat diperlukan. Kepemimpinan pembelajaran (instructional leadership) adalah tindakan yang dilakukan kepala sekolah untuk mengembangkan lingkungan kerja yang produktif dan memuaskan bagi guru, serta pada akhirya mampu menciptakan kondisi belajar siswa meningkat. Dalam fungsinya sebagai pengarah yang inspiratif, kepala sekolah hendaknya dapat mendorong terjadinya peningkatan mutu pengelolaan internal sekolah sehingga memungkinkan terselenggaranya proses pembudayaan literasi yang merangsang para siswa untuk mencapai prestasi literasi yang tinggi.

Untuk mendukung berkembangnya kondisi sekolah yang berbudaya literasi seperti yang diharapkan, sekurang-kurangnya kepala sekolah mampu (1) menentukan arah perubahan, (2) menyeleraskan hubungan kerja SDM di sekolah, dan (3) meningkatkan motivasi berprestasi.

Akhirnya, perlu dikemukakan bahwa tulisan ini memfokuskan pada penggambaran aktivitas-aktivitas yang baik beserta segenap dinamikanya dalam upaya mengawal gerakan literasi, melalui TMS 2015, menjadi realita dalam meretas pembangunan dan pemberdayaan laboratorium kolaboratif pembudayaan literasi pada masa-masa adolesen para siswa di sebuah lembaga pendidikan formal sebagai sebuah studi kasus. Dengan merujuk pada teori-teori psikologi perkembangan masa adolescence, pedagogik, multiple intelligences, instructional leadership, program TMS 2015 dieksekusikan di SMP Negeri 21 Surabaya sekaligus untuk meretas jalan pembangunan dan pemberdayaan laboratorium kolaboratif pembudayaan literasi siswa pada masa-masa adolesen. Tentu, dapat saja penggambaran yang tersaji ada kemiripan atau kesamaan yang berlangsung di 
lembaga lain, baik di dalam maupun di luar negeri. Hal ini terjadi karena memang disadari praksis gerakan ini dapat berupa replikasi, adaptasi, dan atau modifikasi. Namun, jamak pula dalam praksis gerakan ini yang orisinil berupa hasil kreativitas dan inovasi murni dari manajemen dan kepemimpinan di lembaga yang dijadikan lokasi studi ini.

\section{PEMBAHASAN}

Harus diakui, Kota Surabaya telah memiliki Peraturan Daerah (Perda) nomor 16 tahun 2012, ditetapkan pada 26 Juni 2012, tentang Penyelenggaraan Pendidikan yang beberapa klausulnya mengatur tentang budaya membaca bagi warga masyarakat, pendidik, dan tenaga kependidikan, lembaga formal dan nonformal, serta pemerintah daerah. Bahkan lima tahun sebelumnya. 7 Agustus 2009, Perda nomor 5 tahun 2009 tentang Penyelenggaraan dan Pengelolaan Perpustakaan ditetapkan dengan pertimbangan utama untuk menumbuhkan budaya gemar membaca melalui pengembangan dan pendayagunaan perpustakaan. Meski demikian, jika ditelusuri secara kritis dan seksama, kedua Perda ini masing-masing baru memiliki satu Perwali, Perwali nomor 11 tahun 2010 tentang peraturan pelaksanaan Perda nomor 5 tahun 2009 dan Perwali nomor 47 tahun 2013 tentang penyelenggaraan dan pengelolaan pendidikan di Kota Surabaya, sebagai regulasi payung operasionalnya. Kedua Perwali ini pun belum memayungi semua amanat kedua Perda, apalagi secara sistemik adanya kepastian penjaminan pelaksanaan pembudayaan literasi bagi sebuah kota literasi.

Adalah pencanangan Surabaya Kota Literasi yang dilakukan oleh Walikota Surabaya, Ir. Tri Rismaharini, M.T. pada 2 Mei 2014 dapat dijadikan tonggak pembudayaan literasi lebih lempang di Kota Surabaya. Sesungguhnya, sejak itu bertambahlah tebaran peluang-peluang inovatif bagi upaya-upaya pembiasaan membaca, menulis, mendengar, dan berbicara. Upaya pioner pembiasaan literasi yang melempangkan jalan para generasi bangsa menempa diri menjadi insan yang berkebudayaan dan bermartabat lebih tinggi dan tinggi bagi masyarakat Surabaya melalui beragam jalur, jenis, dan jenjang pendidikan. Upaya yang berpeluang menginspirasi lahirnya gerakan yang lebih kreatif dan bermanfaat bidang literasi bagi segenap daerah seantero nusantara. 
Agaknya fenomena kota literasinya Surabaya ini dapat menjadi secercah cahaya untuk meretas jalan yang selama ini terasa gelap dalam pembudayaan literasi. Fenomena ini sekaligus dapat menjawab kegalauan sang begawan sastra Jawa, Suparto Brata. Kegalauan yang diungkap berulang-ulang pada setiap ada kesempatan bahwa kalau orang mau disebut modern, ia harus mau meninggalkan tradisi omong dan jagongan. Menurut beliau, tradisi omong dan jagongan ini kuno. Tradisi bangsa primitif. Bangsa modern sudah tidak membiasakan diri dengan budaya omong-omong dan jagongan. Beliau menyatakan bahwa bangsa modern harus membiasakan diri dengan budaya membaca dan menulis. Karena itu, beliau menegaskan bahwa tantangan Indonesia ke depan adalah mengubah dirinya dari masyarakat yang terkungkung oleh tradisi kelisanan menjadi masyarakat yang bertradisi keberaksaraan (literacy).

Dalam kaitannya dengan pembangunan kultur literasi kelisanan ini, bangsa Indonesia memiliki pengalaman sejarah yang panjang. Pengalaman yang paling dekat adalah pembangunan kultur literasi melalui gerakan persemukaan kelisanan yang dimediasi dengan teknologi komunikasi elektronika, televisi. Secara terstruktur, dan tersentralisasi, kegiatan ini didesain, diisi, dan dikemas selaras dengan hajat hidup masyarakat yang paling dasar. Masyarakat ujung tombak pengeksekusi pembangunan dilibatkan. Kegiatan ini dipublikasi secara efektif dengan predikat "kelompencapir" . Kegiatan "kelompencapir" di TVRI pada era 1980-an ini sebagai wujud teater empiris yang sangat sukses mempergelarkan realitas kehidupan sebagai kegiatan budaya (Irsyad, 2011: 148). Sebagai wahana pendewasaan kemampuan literasi segenap generasi bangsa, "kelompencapir" sukses meniti fungsinya dalam kultur kelisanan. Namun, "kelompencapir" masih harus selangkah lagi untuk memerankan fungsinya sebagai pembangun kultur modern, kultur keberaaksaraan, berupa aktivitas membaca dan menulis secara kreatif, inovatif, dan kritis. Agaknya "kelompencapir" perlu dihidupkan kembali, direvitalisasi dengan predikat baru "kelompencapirlis", dengan tambahan "-lis" sebagai tanda aktivitas tambahan "menulis". Atau tetap dengan predikat "kelompencapir", namun diberdayakan dengan mengedepankan tradisi keberaksaraan (literacy) dalam setiap kali performansi tayangannya. 
Enam belas pekan tepat menjelang setahun pencanangan Surabaya Kota Literasi, dengan semangat memotivasi dan mempersuasi lembaga pendidikan jalur formal di semua jenjang, Dinas Pendidikan Kota Surabaya melauncing kebijakan berani: program Tantangan Membaca 2015 (TMS 2015). Kebijakan cerdas Kepala Dinas Pendidikan Kota Surabaya, Dr. Ikhsan, S.Psi., M.M., melaunchingkan program TMS 2015 pada 2 s.d. 5 Maret 2015 ini patut dan perlu diapresiasi. Untuk mengenal lebih dekat TMS 2015 ini, ada 4 hal yang perlu dipahami.

Apakah TMS 2015? TMS 2015 merupakan (1) upaya meningkatkan minat dan kemampuan membaca siswa, (2) menjadikan membaca sebagai kebiasaan sehari-hari, (3) menjadikan anak Surabaya sebagai pembaca sepanjang hanyat, dan (4) mewujudkan Surabaya sebagai Kota Literasi.

Berikutnya, apa target yang akan dicapai TMS 2015? (1) siswa Surabaya membaca 1.000.000 buku; siswa SD/MI membaca 20-30 buku, siswa SMP/MTs 15 buku, dan siswa SMA/SMK/MA 10 buku.

Apa yang perlu dilakukan oleh siswa dalam TMS 2015? (1) mengisi formulir TMS 2015 yang tersedia di sekolah masing-masing, (2) membaca buku yang dipilih dari daftar buku wajib baca di perpustakaan sekolah, (3) menceritakan kembali ringkasan/resensi isi buku secara lisan untuk siswa SD/MI, secara tertulis untuk siswa SMPMTs/SMA/SMK/MA; format resensi buku tersedia di website: dispendik.surabaya.go.id

Hal penting keempaat dalam TMS 2015, apa yang perlu dilakukan oleh sekolah? (1) mendaftarkan diri melalui website dispendik.go.id pada menu Tantangan Membaca Surabaya 2015, (2) mengisi jumlah buku yang dibaca oleh siswa setiap akhir bulan melalui secara online melalui dispendik.go.id, (3) mengisi daftar nama siswa yang sudah menyelesaikan target TMS 2015 secara online melalui dispendik.go.id

Perlu diketahui pula bahwa dalam catatan historinya, program TMS 2015 ini tak lepas dari peran tangan dingin, keikhlasan, dan semangat membajanya aktivis pegiat literasi Satria Dharma dan kawan-kawan pegiat literasi di Kota Surabaya yang ajeg dan sabar bergerak bersamanya. Tercatat semenjak awal 2014, menurut pengakuannya, program Tantangan Membaca, replikasi dan 
modifikasi dari beberapa lembaga pendidikan negeri Australia, ini sudah diajukan. Namun, disadari bahwa membuat jadi realita ide ini masih harus melalui liku-liku yang panjang sehingga baru pada 24 Februari 2015 program ini disetujui dan disepakati untuk dilaksanakan pada semua sekolah di Surabaya (https://groups.yahoo.com/neo/groups/cfbe/conversations/messages/ 52003). Melalui tulisannya, "Surabaya Kota Literasi”, pada 25 April 2014 Satria Dharma kemudian menawarkan 13 alternatif program yang dapat dilakukan sebuah kota untuk menjadi Kota Literasi. Program-program itu adalah (1) membaca rutin di sekolah, (2) tantangan membaca, (3) seminar dan workshop tentang membaca, (4) membagikan buku bacaan gratis kepada 1000 sekolah, (5) one child one book $(O C O B)$, (6) readingg contest (speed/comprehension reading), (7) meet the author(s), (8) reading award, (9) perpustakaan kelas, (10) story telling competition, (11) book expo, (12) share a story, dan (13) let's write our own story (Pakistyaningsih, 2014: 24-28).

Khusus tentang program "Tantangan Membaca", tawaran program nomor (2), Satria Dharma telah membahas tuntas di http://satriadharma.com/2014/04/17/tantangan-membaca/ dan dalam buku The Rise of Literacy (Dharma, 2014). Pada pandangan Dharma, tantangan membaca sebenarnya adalah upaya untuk mengajak siswa untuk mencintai kegiatan membaca. Ini adalah sebuah upaya untuk menginspirasi siswa untuk menyukai kegiatan membaca agar membaca menjadi kegiatan yang akan terus dilakukannya sampai akhir hayatnya. Jadi, "Tantangan Membaca" sebenarnya adalah sebuah upaya untuk mendorong diri sendiri atau orang lain (dalam hal ini siswa sekolah) untuk membaca sebanyak jumlah tertentu dalam jangka waktu tertentu. Ini bisa dilakukan oleh sekolah, lembaga tertentu, penerbitan, pemerintah, bahkan kita bisa menantang diri kita sendiri. (Dharma, 2014: 53).

Melihat tolok ukur yang ingin dicapai dalam TMS 2015 ini, publik perlu berdecak kagum, sembari berharap semoga pengambil kebijakan kota ini tidak terjebak dalam sindrom miopia alias sindrom rabun jauh (Irsyad, 2007). Atau bahkan sebaliknya, seperti lontaran Dr. Ayu Soetarto bahwa kita (baca: orang Jawa) senangnya yang ndakik-ndakik (Soetarto, 2006). Maksudnya, kita piawai dalam merancang sesuatu yang sulit sehingga kita pun enggan atau sulit melaksanakannya. Kita hobi meniru yang jauh ada di luar sana baru sebatas 
kulitnya. Sementara menyesuaikan isinya dengan konteks bangsa ini malah sering menjadi kekhilafan berjamaah.

Untuk ini, masih ada keyakinan bahwa kebijakan ini dapat bersambut dengan aneka cara pelaksanaan yangg kreatif dan inovatif. Dengan uluran tangan para akademisi, praktisi, dan para penggerak literasi, TMS 2015 dapat membuahkan “... siswa dan guru cerdas dan kreatif karena gemar membaca dan menulis" sebagaimana telah dicita-citakan program ini. Uluran tangan ini sangat berarti bagi pengembangan pembudayaan literasi yang efektif, kreatif, dan menyenangkan.

Keyakinan ini semakin terasa karena ternyata ada pula lembaga-lembaga pendidikan formal yang menggenapi gerakan literasi ini dengan meningkatkan upaya merawat dan merevitalisasi efektivitas sudut baca yang telah cukup waktu tumbuh di Ruang-ruang: Kelas, Guru, BK, Kepala Sekolah. Sebuah gerakan sivitas akademika sekolah sebagai ikhtiar mendekatkan perpustakaan kepada pembacanya. Ada pula lembaga yang memanfaatkan even-even peringatan harihari nasional dan hari-hari peringatan keagamaan dengan aktivitas-aktivitas literasi yang kreatif dan inovatif. Aktivitas literasi ini ada yang berupa "Parade Baca", "Festival Menulis Tokoh Kampung", "X Faktor Literasi”, "Wajahku Awal Citraku", "Sekolahku Tamannya Peserta Didik: Ide-ide Kreatif Inovatif", dan beragam aktivitas literasi cerdas dan kreatif yang bermakna lainnya.

Berkenaan dengan realitas gerakan literasi di Kota Surabaya hingga dewasa ini, dengan mengutip pesan Multatuli, bahwa "Kita tidak berpesta panen padi di sawah, melainkan kita berpesta panen padi yang kita tanam di sawah", Suparto Brata menganggap pesan penulis buku Max Havelaar ini adalah kiasan mengenai buku perpustakaan Indonesia saat ini. Bagi Suparto Brata, kiasan "pesta memanen padi di sawah" ini merupakan pendeskripsian tentang banyaknya penerbitan buku, banyaknya toko buku, dan banyaknya perpustakaan (Pakistyaningsih, 2014: 37-38). Menurut beliau, kalau semua itu berjalan lancar, yang berarti buku diterbitkan banyak, laku keras, toko buku laris, perpustakaan dan Taman Bacaan Masyarakat (TBM) banyak pengujungnya, itu semua merupakan pesta, “... berpesta panen padi di sawah”. Pesta yang bukan “... berpesta panen padi yang kita tanam di sawah". Artinya, kita belum memberdayakan masyarakat menjadi pembaca buku secara sistemik. Jadi, yang 
terjadi baru pada tataran suka beli buku dan suka baca buku karena pertemuan personal dengan orang-orang yang membuat seseorang suka membaca buku. Pembaca buku belum "diproduksi" secara masal dengan sistem pembudayaan literasi yang memiliki kepastian regulasi dan implementasinya. Apalagi TBM di segenap taman kota di se antero Surabaya yang sampai akhir 2014, menurut Badan Arsip dan Perpustakaan Kota Surabaya telah tercatat sebanyak 980 lokasi (Pakistyaningsih, 2014: 3).

Dalam pemikiran Suparto Brata, di mana dan bagaimana "memproduksi massal" pembaca buku? Beliau menjawab dengan tegas sebagai berikut.

"Ya di sekolah! Dari kelas I SD - kelas XII SMA/SMK. Puteraputeri bangsa dibudayakan membaca buku, membaca buku, dan membaca buku setiap hari tanpa jeda. Dan yang dibaca buku dalam berbagai bahasa dan berbagai huruf. Dengan demikian, kalau sudah lulus SLTA, mereka terampil membaca buku berbahasa Indonesia atau berbahasa Inggris dengan huruf ABCD. Terampil membaca buku berbahasa Arab dengan huruf Arab. Terampil membaca buku berbahasa Jepang dengan huruf katakana maupun kanji. Terampil pula membaca buku berbahasa dengan huruf sedunia. Lulus SMA tidak lagi hanya berduyun berebut ke Perguruan Tinggi Negeri (lokal) Indonesia, melainkan dapat langsung bersekolah tinggi di Mesir, Cina, maupun Jepang, Perancis atau Jerman, dan lainnya. Dan perpustakaan-perpustakaan yang menyediakan buku-buku sastera Jawa pun segera disergap para pembaca sastera Jawa karena selama di sekolah dalam rentang waktu 12 tahunan telah dibudayakan membaca buku sastera Jawa. Demikian juga sastera Sunda, sastera Minangkbau, dan sastera daerah se nusantara dikenalkan dan digaulkan secara sistemik karena bahasa daerah merupakan Intangible Cultural Heritage (ICH), kekayaan kultural masyarakat Indonesia yang wajib dilindungi." (Pakistyaningsih, 2014: 38-39)

Menggenapi pemikiran Suparto Brata ini, perlu ada ikhtiar uji ulang gagasan visioner yang membumi Ki Hajar Dewantara (KHD) tentang "Tri Pusat Pendidikan-Pengajaran: keluarga, perguruan, dan pergerakan pemuda". Untuk dapat memperoleh kembali konsep utuh tentang "tri-pusat-pendidikanpengajaran mulai dari makna tektualnya, kontektualnya, hermeneutiknya, filosofisnya hingga ideologisnya, meski tidak di sesi ini dikaji secara tuntas, perlu merekonstruksi atau menganalisis ulang ideografi "bentuk ruang" pembelajaran yang digagas oleh KHD. Hakikinya, beliau lebih banyak menawarkan ruang terbuka dan berbasis keluarga. Sekolah pun beliau sebut "taman" dengan makna kulturalnya yang kental. Oleh karena itu, di samping sekolah, sebagaimana disarankan Suparto Brata, keluarga adalah lembaga resmi dan sah untuk mengembangkan dan memberdayakan budaya membaca ini. Tentu, perlu digenapi 
dengan kurikulum keluarga yang ada kepastian penjaminan mutunya. Gagasan ini dapat menjadi sinergi yang menghasilkan output dan outcome yang handal apabila kolaborasi dan komunikasi antara sekolah dan keluarga terjalin secara harmoni dan diawali dengan niat yang kokoh dan pengimplementasian yang istikomah serta ikhlas.

Di Surabaya kini ..., telah hampir setahun sebulan pencanangan Surabaya Kota Literasi digulirkan. Ia pun diapresiasi segenap kalangan dengan aneka model pengimplementasian. Hampir di semua lembaga pendidikan formal di Surabaya dipampang pajangan yang berbunyi "Surabaya Kota Literasi: menjadikan siswa dan guru cerdas dan kreatif karena gemar membaca dan menulis".

Setakat kini, hakikinya, literasi tidak hanya berupa aktivitas membaca dan menulis semata. Sungguh, perlu keberanian untuk memulai dengan gerakan riil bahwa membaca dan menulis serta mendengar dan berbicara merupakan keperluan. Keperluan bagi setiap orang untuk menjadi insan yang semakin berbudaya dan bermartabat. Insan yang menyadari sebagai makhluk ciptaan Tuhan Yang Mahaesa. Insan yang menyadari bahwa untuk mencapai derajat makhluk utama perlu pembelajaran melalui membaca dan menulis (iqra' dan kalam). Pembelajaran membaca teks, membaca konteks, dan membaca alam sekitar, serta alam semesta perlu dengan niat yang kokoh dan dengan penuh kesabaran diselenggarakan dengan ikhlas oleh segenap pendidik dan stakeholders sekolah.

SMP Negeri 21 Surabaya yang semenjak Februari 2014 memulai tahapan reviu dan revisi atas visi dan misinya yang telah dipancangkan semenjak $1995^{6}$ dan setelah purna menyelenggarakan evaluasi diri sekolah (EDS) tahun 2014, telah diramu visi baru "mengantarkan para siswa menjadi generasi emas yang religius, berakhlak utama, sehat, cerdas, terampil, mandiri, berbudaya literasi, serta peduli lingkungan dan sosial”. Untuk mencapai visi ini, diformulasikan 7 misi yang dijadikan pilar-pilar mengembangkan tujuan-tujuan sekolah. Ketujuh misi ini dirumuskan seperti berikut. Pertama, mengembangkan kurikulum berbasis kompetensi dan visi sekolah serta pembelajaran aktif, kreatif, efektif, bermakna, dan menyenangkan. Kedua, memberdayakan peserta didik selaras dengan minat, talenta, dan keperluan zamannya. Ketiga, memberdayakan pendidik dan tenaga 
kependidikan yang amanah, profesional, dan ikhlas. Keempat, menatalaksanakan sarana dan prasarana pendidikan yang fungsional dan memadai. Kelima, mengelola pembiayaan pendidikan secara transparan dan akuntabel. Keenam, memberdayakan dengan aktif hubungan sekolah dan masyarakat secara sinergis dan simbiosis mutualistis. Ketujuh, mengembangkan budaya literasi, peduli sosial dan lingkungan sekolah yang kondusif.

Dalam ikhtiar mencapai visi yang secara operasional dipandu dengan tujuan-tujuan sekolah yang dijabarkan dari misi sekolah, SMP Negeri 21 Surabaya mengawalnya dengan moto-moto sekolah. Moto "1 Siswa 1 Kabisan"" adalah satu alternatif moto sekolah yang telah dipublikasikan itu. Moto ini dirumuskan dan dipublikasikan untuk memberikan motivasi dan persuasi bagi segenap stakeholders sekolah mencapai visi dan misi sekolah dengan berangkat dari yang sederhana.

Sebagaimana rumusan misi yang ketujuh, mengembangkan budaya literasi, peduli sosial dan lingkungan guna menjadi sekolah yang kondusif, budaya literasi merupakan bagian misi sekolah yang diangkat berdasarkan keperluan objektif para siswa dalam kehidupannya kini yang telah nyata-nyata difasilitasi oleh sistem pertelevisian Indonesia menjadi generasi yang piawai jadi penonton. Penonton yang sangat kuat dalam menyaksikan tayangan televisi meski seharian suntuk. Kebutuhan riil para siswa masa adolesen karena mereka akan segera mengantuk jika dihadapkan pada bahan bacaan sebelum mereka paham dengan yang dibaca, apalagi sempat menangkap cara berpikir penulis buku yang dibacanya, mereka tidak dibiasakan membaca sampai dengan dapat menangkap cara berpikir penulis buku yang dibacanya. Kebutuhan perikehidupannya di masa depannya. Mengapa demikian? Sebab mereka hidup dalam zama ilmu dan pengetahuan. Zaman yang memerlukan kepiawaian menangkap pesan verbal dan nonverbal buku-buku semacam magnum-opus yang dimiliki oleh khasanah pustaka bangsa yang unggul dan berkebudayaan tinggi. Berbekal dari data dan rekomendasi hasil EDS di SMP Negeri 21 Surabaya akhir tahun pelajaran 2013/2014 pula, segenap stakeholders sekolah ini bertekat untuk memulai mendesain dan mengembangkan budaya sekolah yang terbiasakan dan bermakna . 
Budaya Sekolah. Mengembangkan budaya sekolah diawali dengan menyusun dan menetapkan buku Pedoman Sekolah. Pedoman Sekolah yang meliputi kurikulum sekolah, kalender pendidikan/akademik, struktur organisasi sekolah/madrasah, pembagian tugas pendidik dan tenaga kependidikan, peraturan akademik, di antaranya berupa kriteria kenaikan kelas dan pakta kesepahaman sekolah dan orang tua/wali siswa, tata tertib sekolah, serta biaya operasional sekolah: RAPBS, RKAS, dan LRAKS. Satu di antara budaya sekolah yang didesain untuk dikembangkan SMP Negeri 21 Surabaya adalah budaya literasi melalui gerakan literasi yang diawali dengan pembiasaan literasi.

Untuk menjamin kepastian layanan pembiasaan literasi ini, SMP Negeri 21 Surabaya mengembangkan dan menetapkan regulasi sekolah tentang aktivitas dan prestasi literasi siswa untuk dijadikan salah satu variabel penentuan kenaikan kelas. Hal ini merupakan pilar yang disadari perlu dibangun, dirawat, serta difungsikan dengan sungguh-sungguh.

Ikhtiar pengembangan kurikulum literasi keluarga yang ditetapkan melalui proses dialog dan diskusi antara guru, wali kelas, dan kepala sekolah dengan para orang tua/wali siswa dalam forum musyawarah guru-orang tua/wali siswa. Forum ini diinisiasi oleh sekolah dan dilaksanakan setiap menjelang tahun pelajaran baru, tengah semester, dan akhir semester, minimal 5 kali setahun pelajaran. Sebagai langkah awal, orang tua/wali siswa diajak berkolaborasi dengan sekolah untuk mendampingi para putra/putrinya merancang minimal 15 buku yang wajib dibaca dalam kurun waktu 9 bulan. Buku-buku yang dirancang para siswa untuk dibaca dan direfleksikan oleh siswa dalam kurun 9 bulan direkomendasi ${ }^{8}$ oleh orang tua/wali siswa serta Tim Pendampingan Gerakan Literasi SMP Negeri 21 Surabaya. Rekomendasi ini penting mengingat hingga dewasa ini, Indonesia belum memiliki daftar buku layak baca usia adolesen, usia SMP, dari hasil riset yang valid, begitu pula untuk kelompok usia lainnya. Meski Tim Pendampingan Gerakan Literasi SMP Negeri 21 Surabaya telah memfasilitasi dengan daftar judul buku-buku yang telah diakui dunia, regional, nasional, maupun dewan kesenian, maupun lembaga terakreditasi lainnya. Ada buku-buku karya sastra atau nonsastra yang telah memperoleh penghargaan Nobel, Magsaisai Thailand, Dewan 
Kesenian Provinsi, Olimpiade/Festival/Lomba Penulisan Berskala Nasional, dan seterusnya.

Merawat keberlangsungan dan kebermaknaan kualitas pendampingan orang tua/wali siswa atas keberhasilan siswa melakukan aktivitas membaca dan menulis, disadari perlu terus-menerus dilakukan secara terencana dan terevaluasi. Untuk keperluan ini, didesain format untuk forum komunikasi pascabaca antara siswa, orang tua, dan tim pendampingan gerakan literasi ${ }^{9}$.

Fasilitasi Wali Kelas dan Tim Pendampingan Gerakan Literasi SMP Negeri 21 Surabaya dalam upaya agar siswa terbiasa mengasah pembiasaan membaca dan menulis sekurang-kurangnya dilakukan aktivitas-aktivitas (a) memantau Jurnal Membaca Buku Fiksi/Nonfiksi dengan menandatangani rekaman aktivitas membaca siswa dalam pendampingan orang tua/wali siswa setiap hari Kamis pada akhir Jam Wajib Baca 21, (b) memantau Hasil Refleksi Membaca Siswa dalam pendampingan orang tua/wali siswa, (c) memantau dinamika aktivitas membaca siswa; minimal mengawal aktivitas membaca bukubuku yang telah dirancang dan direkomendasi oleh orang tua/wali siswa dan wali kelas dilakukan setiap hari Kamis usai jam wajib baca usai; jika buku-buku yang telah dirancang sudah dibaca dan direfleksi semua sebelum periode waktu usai, siswa menambah buku bacaan baru, Wali Kelas memfasilitasi dengan format rencana tambahan dengan proses seperti aktivitas membaca mulai awal, (d) merekap dan melaporkan prestasi membaca siswa kepada Koordinator Tim Pendampingan Penggerak Literasi, dan (e) khusus menyambut dengan suka cita program TMS 2015, Wali Kelas mengentri progres report prestasi membaca para siswa secara online melalui web TMS 2015.

Yang mendasar dan penting dilakukan dalam gerakan literasi ini ialah faktor keteladanan. Meneladankan pembiasaan pendidik dan tenaga kependidikan dalam aktivitas membaca, menulis, dan mempublikasi karya tulis yang terprogram, tereksekusi, termonitor, terapresiasi, dan terdokumentasi, serta terevaluasi. Untuk ini, dicanangkanlah "Kamis Berbagi aSa". Dengan memanfaatkan waktu 30 menit menjelang berakhir Jam Wajib Baca pada hari Kamis yang 55 menit $^{10}$, para pendidik dan tenaga kependidikan dengan diundi 
urutan menyajikannya, mepresentasikan hasil membaca buku fiksi/nonfiksi di hadapan forum guru/karyawan SMP Negeri 21 Surabaya.

Mendampingi aktivitas membaca, menulis, dan mepresentasikan karya tulis para siswa, seraya menjadi teladan dan teman diskusi bagi para siswa yang memenuhi kendala pembiasaan literasinya adalah kerja besar para guru/karyawan SMP Negeri 21 Surabaya dalam mendidik dan menyelenggarakan pendidikan yang bermartabat untuk mengantarkan para siswa berbudaya adiluhung. Mengapresiasi sekecil apapun aktivitas membaca, menulis, dan presentasi karya tulis para siswa adalah komitmen yang sedang dibangun oleh manajemen SMP Negeri 21 Surabaya.

Aktivitas "Parade Membaca", "Festival Menulis Tokoh Kampung”, "X Faktor Literasi”, “Wajahku Awal Citraku”, “Sekolahku Tamannya Peserta Didik: Ide-ide Kreatif Inovatif Warga Sekolah", dan beragam aktivitas literasi cerdas dan kreatif yang bermakna lainnya sebagai varian alternatif bentuk-bentuk atau wahana apresiasi yang dirancang untuk waktu yang tentatif. Sedangkan untuk waktu yang kontinyu, mengapresiasi aktivitas membaca dan menulis siswa selama empat pekan pada setiap awal pekan memasuki bulan baru. Setiap upacara bendera hari Senin minggu pertama setiap bulan diumumkan nama-nama siswa pembaca buku terbanyak dan siswa penulis terbanyak atas hasil refleksi membaca buku fiksi/nonfiksi. Sertifikat penghargaan gerakan literasi oleh Kepala Sekolah adalah wujud bentuk apresiasi yang disiapkan oleh manajemen SMP Negeri 21 Surabaya. Program TMS 2015 pun menyediakan Sertifikat Penghargaan TMS dari Pemerintah Kota Surabaya.

Menerbitkan buku kumpulan karya tulis terbaik siswa, guru, tenaga kependidikan, dan orang tua/wali siswa, serta pengurus komite sekolah secara berkala, minimal satu tahun sekali juga dirancang sebagai wujud apresiasi terhadap karya mereka. Meski komitmen ini, sampai tulisan ini diangkat, baru sampai pada tahap rancangan, ini diniatkan agar audien dapat menagih kepada manajemen SMP Negeri 21 Surabaya atas buku-buku kumpulan karya tulis terbaik warganya.

Sebagai sebuah model ikhtiar, LabKobuLi-21 mengundang para akademisi, praktisi, penggerak literasi, serta para guru untuk mengkritisi guna 
menemukan dan berproses demi pendewasaan program pembiasaan literasi menuju pembudayaan literasi yang terawat dan bermakna serta berkesinambungan dan berkelanjutan melalui aktivitas literasi secara laboratoris. Sebagai laboratorium, LabKobuLi-21 menyediakan ruang dan waktu untuk berani berulang-ulang mencoba, membuktikan, menemukan, mengkritisi, memperbaiki, mengkomunikasikan, dan mempublikasikan karya laboratorisnya. Para siswa, para guru, para orang tua dan atau wali siswa, para pakar, dan para praktisi literasi diundang secara berkala oleh LabKobuLi-21 untuk menorehkan wahana saling "asah, asih, asuh".

\section{PENUTUP}

Pencanangan Surabaya Kota Literasi telah dilakukan Walikota Surabaya pada 2 Mei 2014 dan pelauncingan program Tantangan Membaca Surabaya 2015 (TMS 2015) oleh Kepala Dinas Pendidikan Kota Surabaya pada 2 s.d. 5 Maret 2015 sungguh melempangkan ikhtiar pembudayaan literasi. Sebagai gerakan, awalnya TMS 2015 terasa sebagai sebuah program "pemaksaan" yang dapat melahirkan "keterpaksaan" namun dapat berbuah "keterbiasaan" yang diperlukan untuk membangun pembudayaan literasi.

Dua kebijakan ini meski belum menjadi sistem yang menjamin kepastian keberlangsungan gerakan, sebagai embrio lahirnya perda dan perwali tentang budaya literasi melalui gerakan literasi dan pembiasaan literasi, ia telah melempangkan teretasnya jalan membangun laboratorium kolaboratif guna pembudayaan literasi (LabKobuLi) yang efektif bagi para generasi bangsa usia adolesen. Dengan LabKobuLi inilah gerakan pengeberaksaraan diberlangsungkan dengan semangat hari ini lebih baik daripada kemarin dan esok lebih baik daripada hari ini.

Untuk menyukseskan gerakan pioner ini, sistem penghargaan dan motivasi, serta pemeranan dan pemungsian kepemimpinan pembelajaran sangat diperlukan. 


\section{DAFTAR PUSTAKA}

Anderson, L.W., Krathwohl, D.R., Airasian, P.W., Cruikshank, K.A., Mayer, R.E., Pintrich, P.R., Raths, J., \& Wittrock, M.C. 2001. A taxonomy for learning, teaching, and assessing: A revision of Bloom's taxonomy of educational objectives. New York: Longman.

Armstrong, Thomas. 2004. Sekolah Para Juara: Menerapkan Multiple Intelligences di Dunia Pendidikan. Diterjemahkan dari Multiple Intelligences in The Classroom $-2^{\text {nd }}$ edition. Bandung: Kaifa.

Dharma, Satria. 2014. The Rise of Literacy. Surabaya: Eureka Academia kerja sama dengan Sarbikita Publishing Sidoarjo.

Direktorat Jenderal Pendidikan Dasar, Kementerian Pendidikan dan Kebudayaan. 2015. Sastrawan Bicara Siswa Bertanya 2015. Jakarta: Kementerian Pendidikan dan Kebudayaan Direktorat Jenderal Pendidikan Dasar.

Erikson, Erik H. 2010. Childhood and Society. Penerjemah: Helly Prajitno Soetjipto dan Sri Mulyantini Soetjipto. Yogyakarta: Pustaka Pelajar.

Irsyad, Chamim Rosyidi. 2007. Menyongsong Pelahiran Perda Pendidikan Kota Surabaya. Surabaya Post edisi 25 April 2007 halaman 3.

Irsyad, Chamim Rosyidi. 2011. Teater Empiris: Laboratorium Realitas Kehidupan. dalam Djatiprambudi, Djuli (Penyunting). Prosiding Seminar Nasional Pendidikan Seni 2011 FBS-UNESA: Membangun Karakter Peserta Didik Melalui Pendidikan Seni. Surabaya: Lembaga Penerbit FBS Unesa.

Ismail, Taufiq. 2005. Tragedi Nol Buku, Tragedi Kita Bersama. Makalah dipresentasikan pada Rakernas IPI, Pekanbaru, Riau, 31 Mei 2005.

Ismail, Taufiq. 2010, Mengejar Ketertinggalan 60 Tahun Dalam Mengajarkan Membaca Buku dan Menulis Karangan di Sekolah Kita. Makalah disampaikan pada Seminar Nasional "Merekonstruksi Sistem Pendidikan Yang Holistik Berbasis Keindonesiaan Untuk Semua" di Hotel Equator Surabaya pada 13 Februari 2010.

Martin, Michael O. \& Mullis, Ina V.S. (Editors). 2013. TIMSS and PIRLS 2011: Relationships Among Reading, Mathematics, and Science Achievement at the Fourth Grade-Implications for Early Learning. Chestnut Hill, MA, USA: TIMSS \& PIRLS International Study Center, Lynch School of Education, Boston College \& Amsterdam, the Netherlands: International Association for the Evaluation of Educational Achievement (IEA)

Masita, Retna (Editor). 2014. Kumpulan Cerpen Sekolah Menengah Pertama: Keluargaku. Surabaya: Pena Semesta.

Mullis, Ina V.S., Martin, Michael O., Foy, Pierre, and Drucker, Kathleen T. 2012. PIRLS 2011 International Results in Reading. Chestnut Hill, MA, USA: TIMSS \& PIRLS International Study Center, Lynch School of Education, Boston College \& Amsterdam, the Netherlands: International 
Association for the Evaluation of Educational Achievement (IEA) IEA Secretariat.

Multatuli. 2014. Max Havelaar. Diterjemahkan dari Max Havelaar: Or the Coffee Auctions of Dutch Trading Company oleh Inggrid Dwijani Nimpoeno. Bandung: Qanita.

Pakistyaningsih, Arini, dkk. 2014. Menuju Wujud Surabaya Sebagai Kota Literasi. Surabaya: Pelita Hati.

Putri, Detyaning Presvianti, dkk. 2013. Kumpulan Cerpen Sekolah Menengah Pertama: Sekeping Cita-cita Anak Negeri. Surabaya: Pena Semesta.

Prasetyo, Eko, Khoiri, Much., \& Suhartoko (Editor). 2014. Boom Literasi: Menjawab Tragedi Nol Buku. Surabaya: Revka Petra Media.

Santrock, John W. 2007. Adolescence (eleventh edition). Alih Bahasa: Benedictine Widyasinta Remaja, edisi kesebelas. Jakarta: Penerbit Erlangga. 